\title{
Clavicle Hook Plate Technique and Functional Results in the Treatment of Acromioclavicular Joint Dislocation
}

\author{
Akromiyoklaviküler Eklem Çıkığı Tedavisinde Klavikula Hook Plak Tekniği ve \\ Fonksiyonel Sonuçları
}

İbrahim Etlii ${ }^{1 *}$ Ömer Faruk Kılıçaslan ${ }^{2}$

1.Să̆lık Bilimleri Üniversitesi Antalya Ĕ̈itim ve Araștırma Hastanesi Ortopedi Kliniği Antalya, Türkiye

2.Să̆lık Bilimleri Üniversitesi Antalya Ĕ̆itim ve Araştırma Hastanesi Ortopedi Kliniği Antalya, Türkiye

\section{ABSTRACT}

Aim: The aim of this study was to evaluate the functional results of patients with acromioclavicular joint (ACJ) dislocation and who were treated surgically with Hook plate (HP) .

Patients and Methods:Patients with ACE dislocation between the years of 20162018 and treated surgically with clavicle KP technique were included in the study. Of the 19 patients, 17 were male and 2 were female. 13 patients had Rockwood Type IV joint dislocation and 6 patients had Rockwood Type V joint dislocation. Functional results were evaluated with modified Constant-Murley shoulder score and standard test protocol. Descriptive statistics were used for data analysis.

Results: The plate was removed at 10 months after the operation due to severe pain and limitation of movement in 1 patient. Two of the patients had plate dislocation. Other patients had no complaints. Degenerative changes were detected in direct radiography in 2 patients. The mean Modified Constant-Murley Shoulder Score of the patients was 65 (min: 26, max: 84). The mean pain score of the patients was 7 . Ten (53\%) patients had moderate and severe pain. Four of the patients had pain at the severity of 8,4 of the patients had pain at the severity of 10 , and 2 of the patients had pain at the severity of 12 . The mean daily life activity score of the patients was 12 (min: 6-max: 20). The flexion and abduction score of the patients were lower than the external rotation and internal rotation. The mean total motion score of the patients was calculated as 27 (min: 8-max: 36).

Conclusion: The HP method in the treatment of ACJ dislocation is early movement and load can be given, surgery is short and easy to apply as a method. However, it causes moderate and severe pain. This may affect functional results.

Keywords, Acromioclavicular joint; dislocation; hook plate, modified Constant-Murley shoulder score.

\section{öz}

Amaç: Bu çalışmada, akromiyoklaviküler eklem (AKE) çıkığı olan ve Kanca plak (HP) ile cerrahi olarak tedavi edilen hastaların fonksiyonel sonuçlarının değerlendirimesi amaçlanmıştır.

Hastalar ve Yöntem: Çalışmaya 2016-2018 yılları arasında AKE çıkığı olan ve cerrahi olarak klavikula KP tekniği ile tedavi edilen hastalar çalışmaya alındı. 19 hastadan 17 'si erkek ve 2'si kadındı. Hastaların 13'ünde Rockwood Tip IV, 6'sında Rockwood Tip V eklem çıkığı vardı.Fonksiyonel sonuçlar Modifiye Constant-Murley omuz skoru ve standart test protokolü ile değerlendirildi. Veri analizinde, tanımlayıcı istatistikler kullanıldı.

Bulgular: Hastaların 1'inde şiddetli ağrı ve hareket kısıtııığı nedeni ile ameliyat sonrası 10. ayda plak çıkartıldı. Hastaların 2'sinde plak çıkığı oluştu. Diğer hastalarda herhangi bir șikayet olmadı. Hastaların 2'sinde radyografide dejeneratif değişiklikler saptandı. Hastaların ortalama Modifiye Constant-Murley Omuz Skoru 65 (min: 26, max:84) bulundu. Ağrı skoru ortalaması 7' idi. Olguların 4'ünde 8 şiddetinde, 4'ünde 10 şiddetinde, 2'sinde 12 şiddetinde olmak üzere toplam $10(\% 53)$ hastada orta ve üzeri şiddette ağıı vardı. Hastaların günlük yaşam aktivite puan toplamı ortalama 12 (min:6-max:20) idi. Hastaların fleksiyon ve abduksiyon puanı eksternal rotasyon ve internal rotasyon hareketine göre daha düşük idi. Hastaların toplam hareket puanı ise 27 (min:8-max:36) bulundu.

Sonuç: AKE çıkığı cerrahi tedavisinde KP yöntemi;erken hareket ve yük verilebilen, cerrahi süresi kısa olan ve uygulanması kolay olan bir yöntemdir. Bununla birlikte orta ve şiddetli düzeyde ağrıya neden olmaktadır. Bu durum fonksiyonel sonuçları etkilemektedir.

Anahtar Kelimeler, akromiyoklaviküler eklem; çıkık; kanca plak, modifiye Constant-Murley omuz skoru.

Recieved Date24.05.2019: Accepted Date:18.06.2019 Published (Online) Date:26.10.2019

*Corresponding Authors: İbrahim Etli, Sağlık Bilimleri Üniversitesi Antalya Eğitim ve Araştırma Hastanesi Ortopedi Kliniği, Antalya, Türkiye. Tel: 05335624553 mail: ietli@hotmail.com

ORCID: 0000-0002-0469-2062 


\section{INTRODUCTION}

$T^{10}$ he acromioclavicular joint (ACJ) is a diarthrodial joint between the clavicle and the acromion, and is statically supplemented with acromioclavicular (AC), coracoclavicular (CC) and coracacromial ligaments, and dynamically supplemented with the deltoid and trapezius muscles. A rapidly degeneration occurs with increasing age in ACJ and loses its functionality after the fourth decade. Acromioclavicular dislocations constitute $12 \%$ of all dislocations around the shoulder joint. ACJ injuries typically occur as a result of falls during sports activities when the arm is adducted. It occurs in young and active individuals, especially when cycling or playing ball [1-3].

In ACJ injuries, rockwood classification is the most common. Type I, II, III are more frequent; Type IV, V and VI are more rare. In Type I, AC or CC ligaments are intact. In Type II, the AC ligament is ruptured and the CC ligament is intact. In Type III, IV, V and VI both AC and CC ligaments were ruptured. Type I and type II are treated nonoperatively. Surgical treatment is recommended for type IV, type V and type VI. Discussions continue for Type III [4-6].

The hook plate (HP) is a metal device that keeps the $A C$ joint in a reduced position by hooking its tip under the acromion and fixing it to the clavicle with screws. Can be used alone or in combination with other ligament repair methods. The advantage of this technique is that it provides a strong and stable structure. Successful results with this technique have been reported. However, the disadvantages of the plate are the compression of the subacromial space, rotator cuff lesions and even the acromial stress fracture of the hook $[1,2,4]$.

The aim of this study was to evaluate the functional results of patients with acromioclavicular joint (ACJ) dislocation and who were treated surgically with Hook plate (HP) with a modified Constant-Murley shoulder score.

\section{PATIENTS AND METHODS}

This retrospective study was started after the approval of the ethics committee. Patients who had ACJ dislocation and who were treated with clavicle HP technique between May 1, 2016 and April
30, 2018 were included in the study. Of the 19 patients included in the study, 17 were male and 2 were female. 13 patients had Rockwood Type IV and 6 patients had Rockwood Type $V$ joint dislocation. The mean age of the patients was $47 \pm$ 14 years. The mean follow-up period was $20 \pm 8$ months. Patients who had ACJ dislocation and who were treated with clavicle HP technique between May 1, 2016 and April 30, 2018 were included in the study. Functional results were evaluated using the modified Constant-Murley shoulder score and standard test protocol. A standard working form was created for the study. Patient information, ACJ dislocation type according to Rockwood classification, hospital stay after surgery, patient follow-up time, Modified Constant-Murley (MCM) shoulder score were recorded. Descriptive statistics were presented in the data analysis.

\section{RESULTS}

The mean follow-up period was $20 \pm 8$ months. The plate was removed at 10 months after the operation due to severe pain and limitation of movement in 1 patient. 2 of the patients had plaque dislocation. Other patients had no complaints (Figure 1). Degenerative changes were detected on X-ray of 2 patients. The mean Modified Constant-Murley Shoulder Score of the patients was 65 ( $\mathrm{min}: 26$, max: 84). The MCM shoulder score of the patients is shown in Table 1.

Table 1. Modified Constant-Murley Shoulder Score

\begin{tabular}{|l|l|}
\hline Modified Constant-Murley Shoulder Score & Mean (min-max) \\
\hline A.Pain (0-15 Points) & $7(3-12)$ \\
\hline B. Daily life activities (0-20 points) & \\
\hline 1.Does your shoulder wake you up from sleep? & 1 \\
\hline 2.Does your shoulder allow daily activity? & 2 \\
\hline 3.Does your shoulder allow entertainment activity? & 3 \\
\hline 4.Which level do you use your hand comfortably? & 6 \\
\hline \multicolumn{1}{|c|}{ Total } & $12(6-20)$ \\
\hline C. Movement (0-40 points) & \\
\hline 5.Flexion & 6 \\
\hline 6.Abduction & 6 \\
\hline 7.External rotation & 8 \\
\hline 8.Internal rotation & 7 \\
\hline \multicolumn{1}{|c|}{ Total } & $27(8-36)$ \\
\hline D. Strength (0-25 points) & $19(0-24)$ \\
\hline A+B+C+D total (0-100 points) & $65(26-84)$ \\
\hline
\end{tabular}



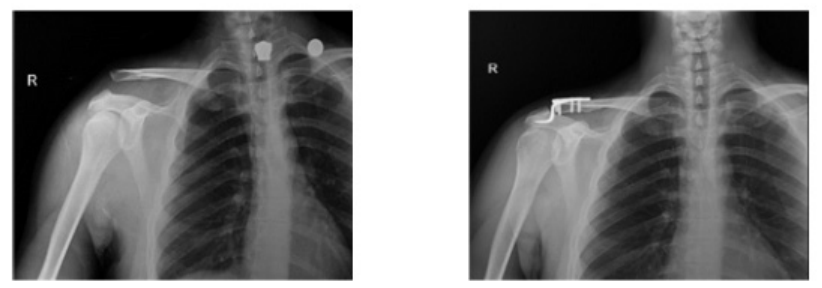

A 39-year-old male patient with a right acromioclavicular joint dislocation after the fall was calculated as the Constant-Murley Shoulder Score of 61 after the surgical treatment with the hook plate.

Figure 1.

The mean pain score of the patients was 7 and 10 patients $(53 \%)$ had moderate and severe pain. Four of the patients had pain at the severity of 8 , 4 of the patients had pain at the severity of 10 , and 2 of the patients had pain at the severity of 12 . Only $3(16 \%)$ of the patients said no to the question of whether your shoulder is waking you up from sleep. The mean daily life activity score of the patients was 12 ( $\min : 6$-max: 20). The flexion and abduction score of the patients were lower than the external rotation and internal rotation. The mean total motion score of the patients was calculated as 27 (min: 8-max: 36).

\section{Discussion}

More than one hundred surgical techniques have been reported in AC joint injuries. However, there are few reports on which methods they achieve the best results. Techniques generally include anatomical reduction; CC ligament reconstruction; and anatomic reconstruction. Techniques that reduce equipment in the AC joint, such as HP, are frequently applied. However, significant changes in joint mechanics result in worsening of short and long-term results [2].

HP applications are increasing in recent years. Leaving HP in place longer than other implants allows sufficient time for joint capsule and ligament healing. In addition, HP's fixation in both vertical and horizontal plan allows physiological movements of the clavicle and consequently decreases complications such as arthritis and stiffness in the joint [4]. The overall complication rate in HP fixation was $11 \%$ and the infection rate was reported as $5 \%[7,8]$. Prolonged storage of the plate may cause acromial osteolysis or fracture, which means that a second operation is required to remove the plate. Complications after HP fixa- tion are caused by the hook contacting the lower surface of the acromion. Pain and discomfort may occur due to this condition. Therefore, HP can be removed again after 3-4 months [1]. Because of these advantages and disadvantages, clinical outcomes related to HP use are variable [2]. In a study examining the HP method in ACJ injuries as a conventional surgical treatment option against arthroscopic double button technique, no clinical difference was found between the two methods.

However, the double-button method among patients had a higher degree of acceptance and tended to better results.[9] In a meta-analysis comparing the Loop suspensory fixation (LSF) method with the HP method, HP's constant score was 90.35 , while it was calculated as 92.48 in the LSF. Again in this study, the chance of complication in LSF group was found to be significantly higher than the HP group [10]. In a prospective study comparing arthroscopic tight rope (TR) fixation with HP fixation, patient satisfaction rate was high in both treatment modalities; returning to work was faster in the TR group, but after a year, both groups returned to their pre-morbid conditions. Again in this study, HP group had postoperative pain and worse functions, and TR group developed more complicated complications including deep infection, recurrent deformity and fracture [5]. These results suggest that the development of complications in arthroscopic or open surgical procedures is similar in terms of functional results. In a multicenter, randomized clinical study conducted by the Orthopedic Trauma Society, patients who were not operated and operated with HP were compared. In this study, MCM shoulder score and disability status after 3 months were better in the group which was not operated and radiographic reduction was better in the operated group. Again, in this study, reoperation and complication rate were found to be higher in the operation group. In this study, there is no clear evidence that operative treatment with HP improves short-term outcomes in all AC joint dislocations [11].

In a study examining the Clavicle HP Technique and Functional Results in the Treatment of ACJ Dislocation, One patient was treated postoperatively at 5 months due to infection and in one patient, the plate was removed in the 3rd postoperative month due to movement restriction, and in one 
case, the plate was removed at the 13th month of the operation due to the fracture of the hook part of the plate. Degenerative changes were observed in four patients and the constant score was 92 [4]. In another study, the overall complication rate was $10.6 \%$. After HP removal, 7 patients had redislocation, 6 patients had superficial soft tissue infection and 1 patient had acromion fracture [7].

The plate was removed at 10 months after the operation due to severe pain and limitation of movement in 1 patient. 2 of the patients had spontaneous plate dislocation. Complications were similar to other studies. In our study, the mean MCM shoulder score of the patients was 65 (2684). Our scores were lower than the other studies. When we analyzed the MCM shoulder scores in detail, the patients' mean pain score was 7.10 patients $(53 \%)$ had moderate and severe pain. 4 of the patients had pain at the severity of 8,4 of the patients had pain at the severity of 10 , and 2 of the patients had pain at the severity of 12 . Only $3(16 \%)$ of the patients said no to the question of whether your shoulder is waking you up from sleep. These results are important because of the high severity of pain. Pain affects the movements may have led to decrease in other scores. As a matter of fact, the average daily activity score of the patients was 12. The flexion and abduction score of the patients were lower than the external rotation and internal rotation. The mean total score of the patients was 27 . In other studies, the Constant score was not examined in detail. Therefore, our study is different from other studies.

Limitations: The retrospective design of our study and the small number of cases may be considered as limitations. However, it may contribute to national data and/or the systematic reviews and meta-analyzes [12] which will be done together with other studies originating from our country.

Conclusion: The HP method in the treatment of ACJ dislocation is early movement and load can be given, surgery is short and easy to apply is a method. However, it causes moderate and severe pain. This may affect functional results. Therefore, larger studies are needed to investigate the functional results of the HP method. Although our study is single-centered and the number of cases is small, we believe that it will shed light on future studies.

Funding sources: The authors received no financial support.

Conflict of interest: The authors have nothing to disclose and there are no conflicts of interests.

\section{REFERENCES}

1. van Bergen CJA, van Bemmel AF, Alta TDW, van Noort A. New insights in the treatment of acromioclavicular separation. World J Orthop. 2017;8(12):861-73. PMID: 29312844

2. North AS, Wilkinson T. Surgical reconstruction of the acromioclavicular joint: Can we identify the optimal approach? Strategies Trauma Limb Reconstr. 2018;13(2):69-74. PMID: 29978445

3. Özden R, Uruç V, Duman İG, Doğramacı Y, Kalacı A, Kömürcü E. Endobutton technique for the treatment of acute acromioclavicular joint dislocations. Dicle Medical Journal 2014;41(2):268271. doi: 10.5798/diclemedj.0921.2014.02.0414

4. Baran MA, Dinçel YM,Beytemür O, Çağlar S, Adanır O, Alagöz E. Clavicle Hook Plate Technique and Its Functional Results in the Treatment of Acromioclavicular Joint Dislocation. Kafkas J Med Sci 2015; 5(1):13-17. doi: 10.5505/kjms.2015.02418

5. Athar MS, Ashwood N, Arealis G, Hamlet M, Salt E. Acromioclavicular joint disruptions: A comparison of two surgical approaches 'hook' and 'rope'.J Orthop Surg.2018;26(1):2309499 017749984.PMID: 29353523

6. Esenyel CZ, Öztürk K, Bülbül M, Ayanoğlu $S$, Ceylan $H H$, Öztürk K, Bülbül M, Ayanoğlu S. Akromiyoklaviküler eklem çıkıklarında korakoklaviküler bağ tamiri ve vida ile tespit. Acta Orthop Traumatol Turc 2010;44(3):194-198. PMID: 21088459

7. Kienast B, Thietje R, Queitsch C, Gille J, Schulz AP, Meiners J. Mid-term results after operative treatment of rockwood grade III-V acromioclavicular joint dislocations with an AC-hook-plate. Eur J Med Res 2011;16: 52-56. PMID: 21463981

8. Modi CS, Beazley J, Zywiel MG, Lawrence TM, Veillette CJ. Controversies relating to the management of acromioclavicular joint dislocations. Bone Joint J 2013; 95-B: 1595-1602. PMID: 24293587

9. Jensen G, Ellwein A, Voigt C, Katthagen JC, Lill H .Injuries of the acromioclavicular joint: Hook plate versus arthroscopy. Unfallchirurg. 2015;118(12):1041-53. PMID: 26601846

10. Arirachakaran A, Boonard M, Piyapittayanun $P$, Kanchanatawan W, Chaijenkij K, Prommahachai A, Kongtharvonskul J. Post-operative outcomes and complications of suspensory loop fixation device versus hook plate in acute unstable acromioclavicular joint dislocation: a systematic review and meta-analysis. J Orthop Traumatol 2017;18:293-304. PMID: 28236179

11. Canadian Orthopaedic Trauma Society. Multicenter Randomized Clinical Trial of Nonoperative Versus Operative Treatment of Acute Acromio-Clavicular Joint Dislocation. J Orthop Trauma 2015; 29: 479-487. PMID: 26489055

12. Aslan A. Systematic Reviews and Meta-Analyses Acta Med. Alanya 2018;2(2):62-63. [Turkish] DOI: 10.30565/medalanya.439541 
How to cite this article/Bu makaleye atıf için:

Etli İ, Kılıçaslan ÖF. Clavicle Hook Plate Technique and Functional Results in the Treatment of Acromioclavicular Joint Dislocation. Acta Med. Alanya 2019;3(3):226-230. doi:10.30565/medalanya.569893 